Diabetologia $9,403-412(1973)$

(C) by Springer-Verlag 1973

\title{
Dynamics of Pancreatic $\beta$-Cell Responses to Glucose
}

\author{
L. - $\AA$. Idah1 \\ Department of Histology, University of Umea, S.901 87 Umea, 6, Sweden \\ Received: February 7,1973 and in revised form: May 29, 1973
}

\begin{abstract}
Summary. Microperifusion was used to study the dynamics of insulin release and metabolic changes in pancreatic islets microdissected from $a b / o b$-mice. When the islets were suddenly exposed to a high glucose concentration, their content of glucose 6-phosphate and fructose-1, 6-diphosphate started to rise immediately, whereas a secretory response was not observed until after about 80 see. This is consistent with the hypothesis that glucose metabolism initiates insulin release. Fasting the donor animals for $18 \mathrm{~h}$ reduced the initial phase of glucosestimulated release but left the rise of glucose-6-phosphate, as well as the late phase of sustained release, unaffected. The use of a tissue culture medium (TCM 199) instead of Krebs-Ringer bicarbonate buffer as the basal medium increased the secretory responses to glucose, particularly
\end{abstract}

the initial phase, both in islets from fed and fasted mice. However, the difference between fed and fasted mice remained. Theophylline did not restore the impaired initial secretory response after fasting. The responses of islet fruotose-1,6-diphosphate and adenosinem-5-triphosphate to glucose depended on the nutritional state of the animals and on the type of basal medium. No consistent correlation was observed between the changes of these substrates and the dynamies of insulin release.

Key words: Glucose metabolism, islet adenosine-5-triphosphate, insulin release, intermediary metabolism, microperifusion, $o b / o b$-mice, pancreatic $\beta$-cells. starvation, TCM 199, theophylline.
It is not clear how the pancreatic $\beta$-cells measure the surrounding glucose concentration and respond with an appropriate rate of insulin release. Most attention has been devoted to the hypothesis that stimulus recognition involves metabolism of glucose. The possible existence of a more direct glucose receptor has also been discussed. In support of the former alternative several authors have demonstrated correlations between rates of insulin release and various parameters of glucose metabolism at steady-state. However, when exposed to an abrupt rise of glucose concentration the $\beta$-cells do not attain a steady-state until several minutes after the environmental change [1]. The secretory response is distinctly multiphasic with time, and it has been suggested that the initial and late phases of response depend on different types of glucose recognition. It is therefore desirable to look for correlations between glucose metabolism and insulin release also during the initial phase of glucose-stimulated insulin release. In particular it seems important to look for changes of metabolic intermediates and cofactors that may occur parallel or prior to the enhancement of insulin release. The lack of experimental techniques with sufficient resolution in time has been a major obstacle to systematio studies of this kind. Quite recently the perfused rat pancreas preparation has been utilized for this purpose [2].

In the present study, a newly constructed microperifusion system has been used for freeze-stop measurements of glucose-6-phosphate, fructose-1,6-diphosphate and adenosine-5-triphosphate in islets microdissected from obese-hyperglycemic mice. The concentration of metabolites and rates of insulin release were recorded at a series of intervals after a sudden rise of extracellular glucose concentration. Comparisons were made between islets from fed and fasted mice, because fasting is known to suppress insulin release in response to glucose, a phenomenon that has been attributed to inhibition of glucose phosphorylation in the $\beta$-cells [3].

\section{Materials and Methods}

\section{Chemicals}

D-glucose was obtained from Baker and Adamson Products, Morristown, New Jersey, U.S.A. and sodium lactate $(70 \%, \mathrm{w} / \mathrm{v}$ in water) from Hopkins \& Williams, Cladwell Heath, Essex, England. Crystalline human serum albumin came from Kabi AB, Stockholm, Sweden. Tissue culture medium 199 (TCM 199) was obtained from National Bacteriological Laboratories, Stockholm, Sweden. Reagents for insulin assay were kindly donated by Novo Industri A/S, Copenhagen, Denmark, who also prepared $2 \mathrm{X}$ crystallized mouse insulin. All the other biochemicals and the enzymes came from Boehringer \& Söhne GmbH, Mannheim, Germany. Reagents of analytical grade were used throughout.

\section{Animals and Microdissection of Islets}

Six to 8 months old obese-hyperglycemic mice (gene symbol: $o b / o b$ ) of both sexes and their lean litter mates were obtained from the Umea colony [4]. The animals to be fasted were placed on a metal net floor for $17-18$ $h$ in order to prevent nibbling of wood shavings and 
excrement. Fresh pancreatic islets were isolated by freehand microdissection at $2-4^{\circ} \mathrm{C}$ [5] in Krebs-Ringer bicarbonate buffer [6] or TCM 199 [7] which were equilibrated with $\mathrm{O}_{2}: \mathrm{CO}_{2}(95: 5)$ and supplemented with human serum albumin $(0.5 \%, \mathrm{w} / \mathrm{v})$. The dissection medium contained glucose in the same concentration as that used during subsequent preincubation.

\section{Experimental Design}

The perifusion system and procedures have been described in detail elsewhere [8]. Briefly, isolated pancreatic islets were distributed in up to 9 identical tissue chambers run in parallel. Continuous non-recycled perifusion was performed at a rate of about $35 \mu 1 / \mathrm{min}$ for each tissue chamber. The small size of the tissue chambers $(4.5 \mu \mathrm{l})$ ensures good resolution of the multiphasic secretory response. A prestimulatory period of 45 or 60 min preceded the period of glucose stimulation. The moment of switching from a reservoir containing low glucose medium to one containing high glucose concentration is denoted as zero time. From this moment it took $30 \mathrm{sec}$ for the medium to reach the tissue chamber and a further 30 sec to reach the sampling port. Samples of effluent were collected for assay of ghucose and insulin. The tissue chambers were successively disconnected and plunged into melting isopentane $\left(-160^{\circ} \mathrm{C}\right)$ after different periods of time. The islets were freeze-dried and weighed prior to analysis of their content of glucose-6-phosphate (G6P), fructose-1,6-diphosphate (FDP) or adenosine-5-triphosphate (ATP).

\section{Assay Procedures}

Glucose was determined with an enzymatic fluorometric technique $[9,10]$ in diluted $(1: 250)$ samples of medium. Insulin was assayed radioimmunologically [11] in duplicates using crystalline mouse insulin standard.

The analyses of metabolic intermediates in the islets were based on NAD- or NADP-dependent enzymatic methods combined with enzymatic cycling $[9$, $12,13]$. Oil wells were used as reaction vessels $[13,14$, 15]. Triplicate samples of reagent blanks and standards covering the sample range were carried through the entire procedure together with duplicate samples of islet extracts. The compositions of the reagents for assaying $\mathrm{G} 6 \mathrm{P}$ or ATP were as described by Matschinsky et al. [13]. The cycling medium used in this context [16] gave an amplification of 7000 to 10000 times per $h$. The reagent for FDP assay was composed of $1 \mathrm{mM}$ EDTA, $1 \mathrm{mM}$ mercaptoethanol, $1 \mathrm{mM}$ sodium arsenate, $0.02 \mathrm{mM} \mathrm{NAD}, 0.1 \%(\mathrm{w} / \mathrm{v})$ human serum albumin, $4 \mu \mathrm{g} / \mathrm{ml}$ aldolase, $10 \mu \mathrm{g} / \mathrm{ml}$ glyceraldehyde-3-phosphate dehydrogenase and $1 \mu \mathrm{g} / \mathrm{ml}$ triosephosphate isomerase in 0.2 M imidazole buffer, $\mathrm{pH}$ 7.4. The NAD-dependent cycling medium contained $40 \mu \mathrm{g}$ lactic dehydrogenase (charcoal treated and recrystallized) and $200 \mu \mathrm{g}$ glutamic dehydrogenase per $\mathrm{ml}$. The cycling reaction amounted to approximately 3000 cycles $/ \mathrm{h}$ at $38^{\circ} \mathrm{C}$.
Some modifications of a technical nature were made in order to simplify routine work with this kind of assay and to optimize the yield of information from the available amounts of tissue. After freeze-drying and weighing, the islets from each tissue chamber were pooled and extracted in $0.015 \mathrm{M} \mathrm{HCl}(0.5 \mu \mathrm{l} / \mu \mathrm{g}$ islet dry weight) for $10 \mathrm{~min}$ at $100^{\circ} \mathrm{C}$. Aliquots of the extracts were then immediately mixed with equal amounts of $0.1 \mathrm{M} \mathrm{NaOH}$ and heated for $20 \mathrm{~min}$ at $60^{\circ} \mathrm{C}$ for determination of FDP or ATP. Those acid and alkaline extracts, or fractions thereof, which were not used immediately were frozen and stored at $-90^{\circ} \mathrm{C}$ for assay or reassay later on. No detectable decrease of the intermediates in question was encountered after 7 days, the maximum time of storage allowed. The initial steps of the analyses, including the cycling reaction in the case of G6P and FDP, were performed in oil wells equipped with a transparent base (FEP-foil $0.25 \mathrm{~mm}$, Du Pont de Nemours \& Co., Wilmington, Delaware, U.S.A.) and illuminated from below. The wells were filled with mineral oil (Aero Hydraulic 1, Svenska BP AB, Stockholm, Sweden) filtered through $0.45 \mu$ Millipore filter. Commercially available constriction pipettes (H. E. Pedersen, Copenhagen, Denmark) were used throughout. Additions of blanks, standards, extracts and the sub. sequent reagents were performed with the racks of oil wells placed on a cooled metal plate $\left(-1.5^{\circ} \mathrm{C}\right)$ underneath a low-power stereo-microscope. Ovens set at the appropriate temperature and containing a layer of sand were used for incubation and heating of the oil wells.

\section{Results}

\section{Rapidity of Onset of Insulin Release and Metabolite Changes after a Sudden Rise of Glucose Concentration}

The purpose of the present investigation was to study the metabolic and secretory response of $\beta$-cells after a sudden rise of the peri-insular glucose concentration from $3 \mathrm{mM}$ to $17 \mathrm{mM}$. Fig. 1 shows that the system used for creating such a square-wave function of glucose concentration with time was near ideal. About 60 sec after the change between supplying reservoirs, the glucose concentration at the sampling port started to rise. The portion of effluent collected over the next $40 \mathrm{sec}$ had a glucose concentration of almost $15 \mathrm{mM}$. The delay of $60 \mathrm{sec}$ before the glucose concentration started to rise is identical with the time required for medium to flow from the supplying reservoir, via the perifusion chamber, to the sampling port.

In contrast to the concentration of glucose in effluent, that of insulin remained at the prestimulatory value for as long as 140 sec after the change of supplying reservoirs. This means that a significant secretory response was not detectable at the sampling port until $80 \mathrm{sec}$ after the glucose concentration in the effluent had risen to about $15 \mathrm{mM}$. The first secretory response was followed by a reduction of the release rate, resulting in an initial peak that lasted for about $2 \mathrm{~min}$. 
The concentrations of $\mathrm{G} 6 \mathrm{P}$ and FDP in islets started to rise at the same time as the peri-insular glucose concentration. As soon as 70 sec after changing supplying reservoirs the concentration of $\mathrm{G} 6 \mathrm{P}$ was $50 \%$ higher and that of FDP $35 \%$ higher than the values reached at $3 \mathrm{mM}$ glucose. Thus these metabolites had increased considerably 40 sec before there was any sign of stimulated secretion. The concentration of $\mathrm{G} 6 \mathrm{P}$ reached an apparent steady-state within about $3 \mathrm{~min}$, whereas the concentration of FDP, measured in the same islet specimens, seemed to go on increasing at the end of the experiment.

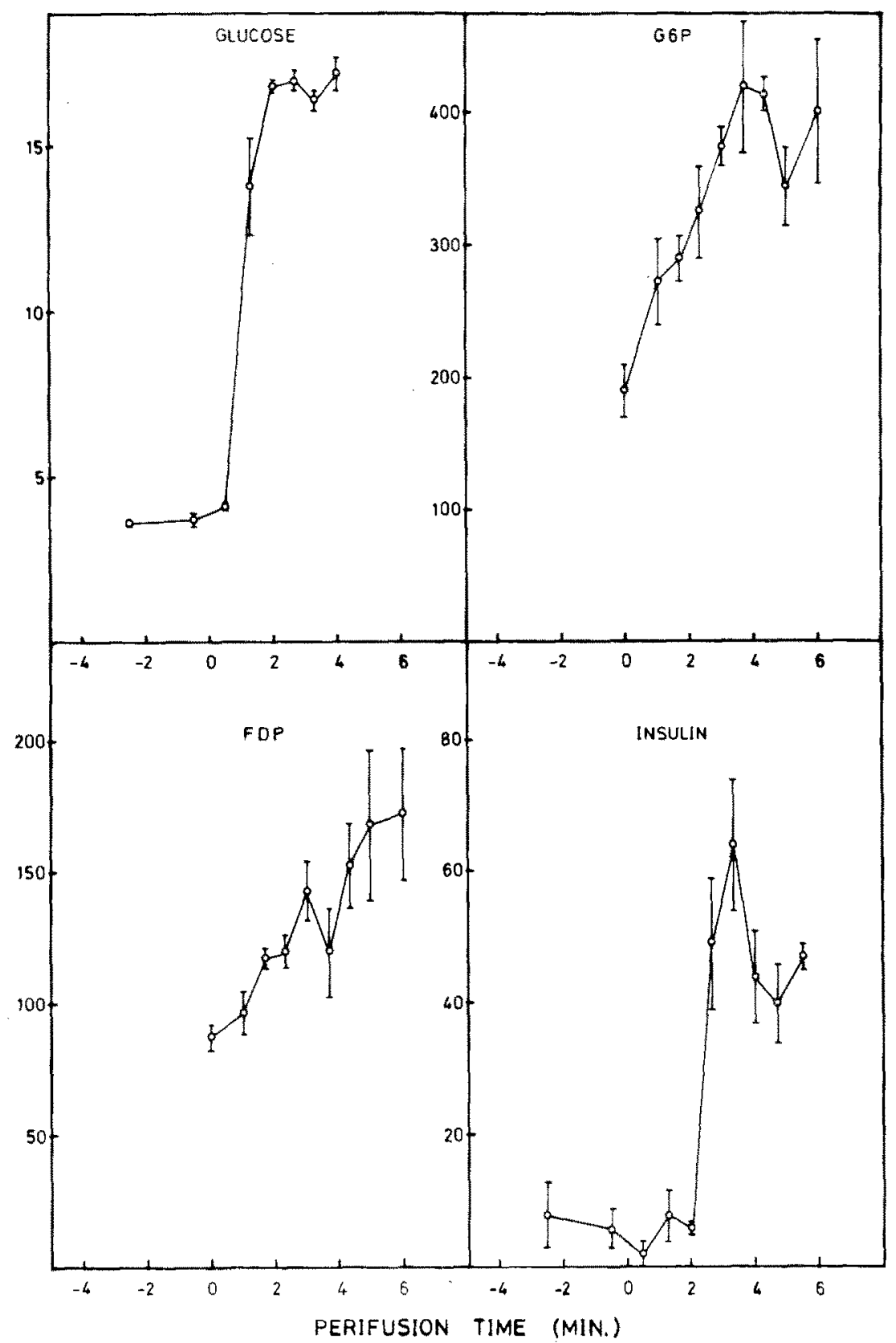

Fig. 1. Effect of a sudden transition from $3 \mathrm{mM}$ to $17 \mathrm{mM}$ glucose on islet content of G6P and FDP and on the release of insulin. Islets from fasted (18h) ob/ob-mice were perifused for $60 \mathrm{~min}$ with TCM 199 containing $5 \mathrm{mg} / \mathrm{ml}$ albumin and $3 \mathrm{mM}$ glucose. At the end of this period two 60 sec samples were collected for the determination of glucose and insulin in the effluent. The medium was then changed to contain $17 \mathrm{mM}$ glucose. The moment of switching between medium reservoirs is denoted as zero time. Continuous sampling was then performed at intervals of 40 or 60 sec. The points representing islet content of intermediates have been moved 30 sec to the right in the diagrams to com. pensate for the phase difference between the tissue chambers and the sampling port. Glucose in the effluent is given as $\mathrm{mM}$. G6P and FDP are expressed as umoles/kg dry islet, and insulin release as $\mathrm{pg} / \mu \mathrm{g}$ dry islet per min. Mean values \pm S.E.M. for 3 experiments 
Effect of Fasting or Medium Composition on the Dynamics of Insulin Release

Fig. 2 shows the effect of fasting on glucose-induced insulin release from islets perifused with KRB buffer. The release of insulin from islets of fed mice was characterized by a rapid initial elevation of moderate amplitude directly followed by a slow increase. Fasting delayed the $\beta$-cell response to glucose for more than $10 \mathrm{~min}$, after which there was a smooth increment of the release rate. There was no difference between the islets from $o b / o b$-mice and their lean litter-mates in this respect. fused with KRB buffer. As shown in Fig. 4, the difference in the amount of insulin released between islets from fed and fasted mice was about the same whether KRB buffer or TCM 199 was used as perifusion medium. With both types of medium, fasting reduced the initial phase of the $\beta$-cell response to glucose $(0-20 \mathrm{~min})$, whereas the secondary phase of sustained release was relatively unaffected.

Theophylline is often used to enhance the insulin response to various stimuli. The addition of this substance to the perifusion medium amplified the response to glucose about ten times (Fig. 5). The release patterns

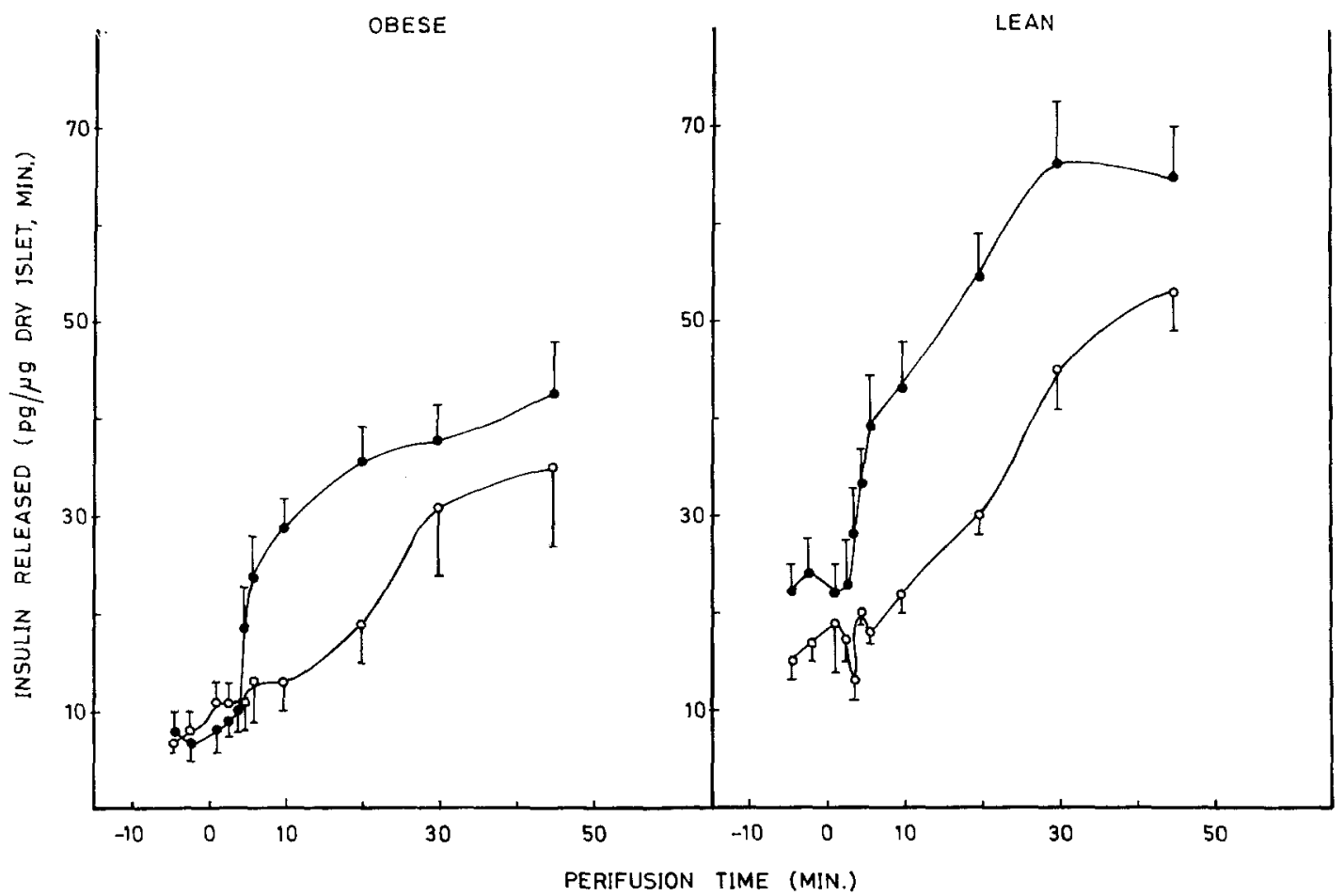

Fig. 2. Effect of fasting (17-18 h) on the dynamics of glucose-induced insulin release. Islets from fed (solid circles) or fasted (open circles) ab/ob-mice (left) and their lean litter mates (right) were perifused with KRB buffer containing $5 \mathrm{mg} / \mathrm{ml}$ albumin and $3 \mathrm{mM}$ glucose. After a prestimulatory period of 45 (obese) or $60 \mathrm{~min}$ (lean) the perifusion medium was suddenly switched to the same kind of medium containing $17 \mathrm{mM}$ glucose. $1 \mathrm{~min}$ samples of effluent were taken for insulin assay at various times before and after switching between the medium reservoirs. Mean values \pm S.E.M. for 6 experiments. Statistical evaluation of the delay induced by fasting was performed by Student's t-test for paired samples. The values at -3 min were taken as prestimulatory level. The insulin secretory response was statistically significant at $4 \mathrm{~min}$ for islets from fed mice (obese $11.8 \pm 4.1 \mathrm{pg}$ insulin/ug dry islet, min; $p<0.05$ and lean 11.2 $\pm 3.8 \mathrm{pg} / \mu \mathrm{g}$ dry islet, $\min ; p<0.05$ ) and at 20 min for islets from fasted mice (obese $10.2 \pm 2.7 \mathrm{pg}$ insulin/ $\mathrm{gg} \mathrm{dry}$ islet, $\min ; p<0.02$ and lean $13.0 \pm 2.7 \mathrm{pg} / \mu \mathrm{g}$ dry islet, $\min ; p<0.005$ )

When TCM 199 was used instead of KRB buffer (Fig. 3), $17 \mathrm{mM}$ glucose induced an initial secretory response from the islets of fasted mice as well as from those of fed controls. The magnitude of the initial response was substantially greater in the islets from fed mice. These islets rapidly adjusted their insulin release to a constant rate. Those from fasted mice, on the other hand, exhibited an increasing rate of insulin release after the moderate initial response, much like the pattern observed when islets from fed mice were peri- obtained with islets perifused with theophylline in KRB buffer were very similar to those observed when islets were perifused with TCM 199. The islets from the fed mice rapidly attained a constant release rate. Insulin release from islets of fasted mice was initially reduced but gradually approached the rate observed with islets from fed mice. Thus again, the effect of fasting expressed itself as a reduction of the initial secretory response to a square-wave glucose stimulus. 


\section{Effect of Fasting or Medium Composition on the Islet Content of Metabolites}

Administration of $17 \mathrm{mM}$ glucose invariably induced a prompt increase of the islet content of G6P (Figs. 1,6 and 7). This intermediate remained elevated throughout the experiments up to $45 \mathrm{~min}$. Both FDP and ATP were, on the other hand, markedly influenced by fasting and type of medium. When KRB buffer was used as perifusion medium, stimulation with $17 \mathrm{mM}$ glucose induced a significant rise of these metabolites only in islets from fed animals (Figs. 6 and 7 ). The observed increase in FDP content was, however, rather slow and

\section{Discussion}

Three methodological problems need particular attention in attempts to study rapid metabolic changes in the pancreatic $\beta$-cells. First of all, the investigated tissue specimens must contain a very high proportion of intact $\beta$-cells. This fundamental requirement is met here by the use of islets microdissected from $a b / o b-$ mice. Second, the incubation procedure should permit a sharp resolution in time with minimum damping and distortion of the metabolic events. Freeze-stop techniques in combination with intra-arterial perfusion [17]

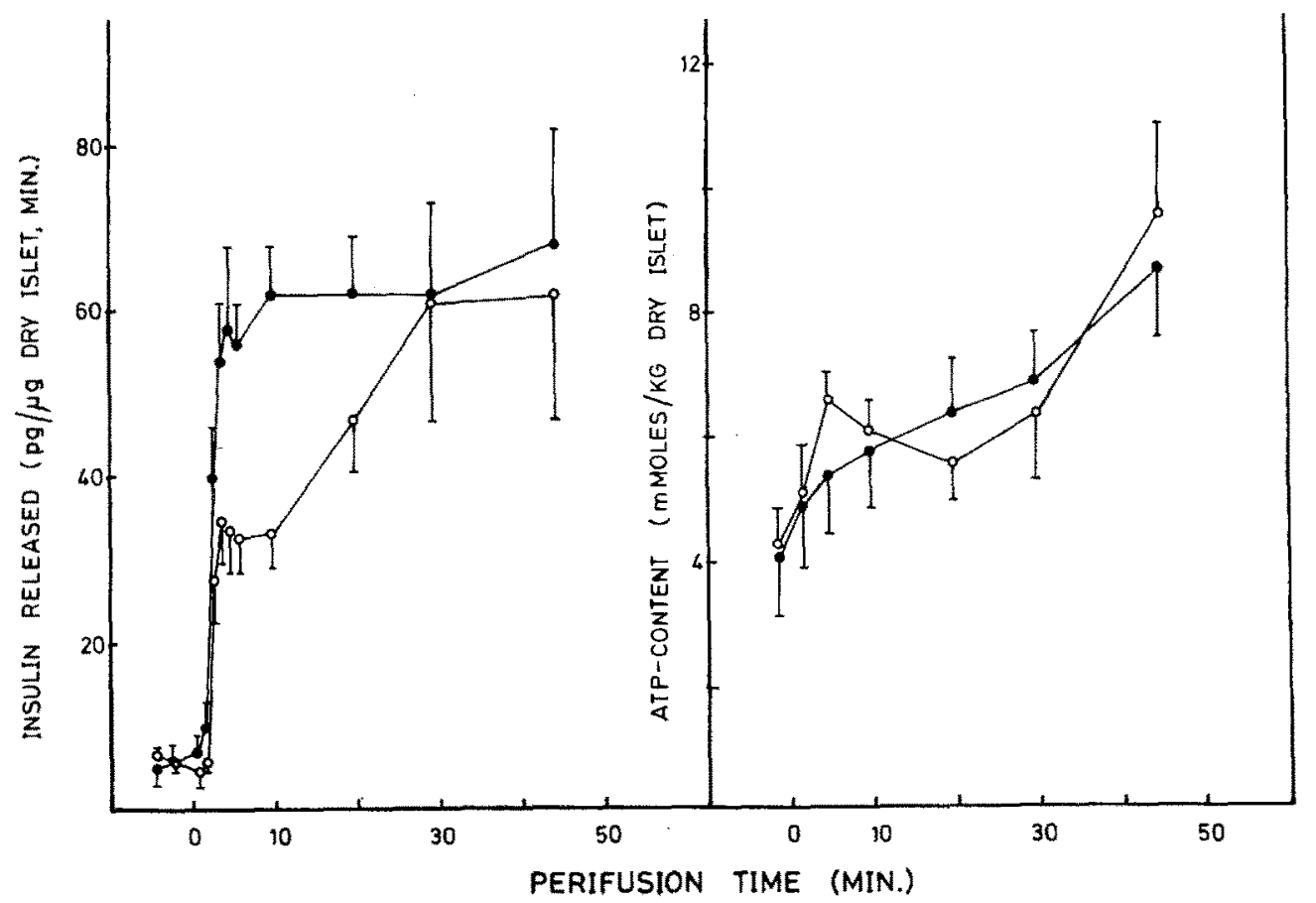

Fig. 3. Dynamics of insulin release and ATP content in response to glucose. Effect of fasting on islets from ob/obmice perifused with TCM 199. After 45 min with $3 \mathrm{mM}$ glucose the perifusion medium was suddenly switehed to the same kind of medium containing $17 \mathrm{mM}$ glucose. Five separate experiments were performed both with fed (solid circles) and fasted animals (open circles). Mean values \pm S.E.M. for insulin release (left) and ATP content (right)

was preceded by a delay of more than $10 \mathrm{~min}$. The concentration of A'TP in the same islets from fed animals exhibited a clearly biphasie variation with time. There was a significant increase of ATP only between 4 and 10 min after the medium change and at the end of the experiments. In addition the islet content of ATP was almost $50 \%$ lower in the fasted group at the end of the prestimulatory period (Figs. 6 and 7 ).

When perifusing with TCM 199 instead of KRB buffer, $17 \mathrm{mM}$ glucose induced a prompt increase in the content of FDP in islets from fasted mice (Fig. 1). In these islets glucose also elicited a prompt increase in ATP with a superimposed biphasic tendency (Fig. 3). This is in contrast to the islets from the fed animals, where glucose stimulation resulted in a more continuous increase of ATP. or perifusion of microdissected islets [8] are presumably the best methods available from this point of view. Third, it is necessary to consider to what extent the exchange of substances between the ineubation medium and the immediate exterior of the individual cells might influence the recorded kinetics. To eliminate such an influence one would ideally use isolated $\beta$-cells in suspension, but a metabolically intact preparation of this kind remains to be developed. When the whole pancreas is perfused or microdissected islets are perifused, diffusion through the extracellular space must be taken into account. Some information about this process can be obtained from studies on the uptake of radioactively labelled L-glucose by microdissected islets of $o b / o b$-mice. This compound is excluded from the $\beta$-cells but most probably diffuses like $\mathrm{D}$-glucose in 
the extracellular space [18]. At $37^{\circ} \mathrm{C}$ the islet uptake of L-glucose reaches its half-maximum value within 45 sec [19]. This time may be compared with that required for G6P to achieve half its total increase in the present study. As shown in Fig. 1, G6P reached this point 20-60 sec after the sudden increase of periinsular glucose concentration. It is probable therefore that diffusion of glucose in the islet extracellular space markedly affected the observed rate of G6P increase.

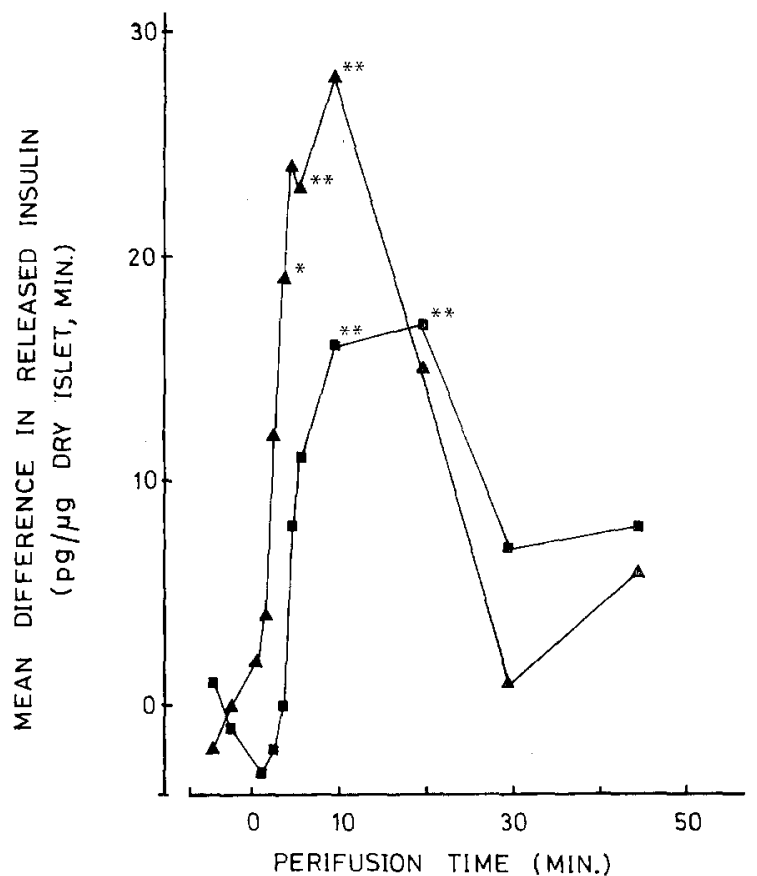

Fig. 4. Difference in rate of insulin release between islets from fed and fasted $o b / o b$-mice as a function of time after the onset of glucose stimulation. The curves were calculated from the data shown in Figs. 2 and 3, representing perifusion with KRB buffer ( $\mathbf{n}$ ) and TCM 199 (А). Significance levels were calculated with Student's t-test. ${ }^{*} p<$ $0.05 ; * *<0.01$

To investigate the time characteristics of the microperifusion apparatus, model experiments have previously been performed without islets in the tissue chamber. When in those experiments insulin was suddenly fed to the chamber, the concentration of insulin in effluent changed completely over a 60 sec interval [8]. Under certain conditions in the present study a similar rise-time was observed for insulin emanating from the islets and representing the initial secretory response to glucose. This rapid rise of insulin was unexpected in view of the time required for much smaller molecules to equilibrate by diffusion in the islet extracellular space [18]. A probable explanation is that the major quantity of insulin was released from superficially situated $\beta$-cells. Such an assumption could also explain why in batch-type experiments large islets secrete less insulin per unit dry weight than do small islets from the same pancreas [20]. Since islets of uniform size are usually employed, it seems doubtful whether express- ing data in relation to the surface area is preferable to the practice of expressing data per unit dry weight.

Although glucose is often said to induce "prompt" or 'rapid' stimulation of insulin release, several authors have observed a time-lag between the rise of glucose concentration and the onset of the secretory response. Lag periods ranging from less than 30 sec to more than 2 min have been reported $[21,22,23,24]$. The existence of such a lag made it possible to show here that

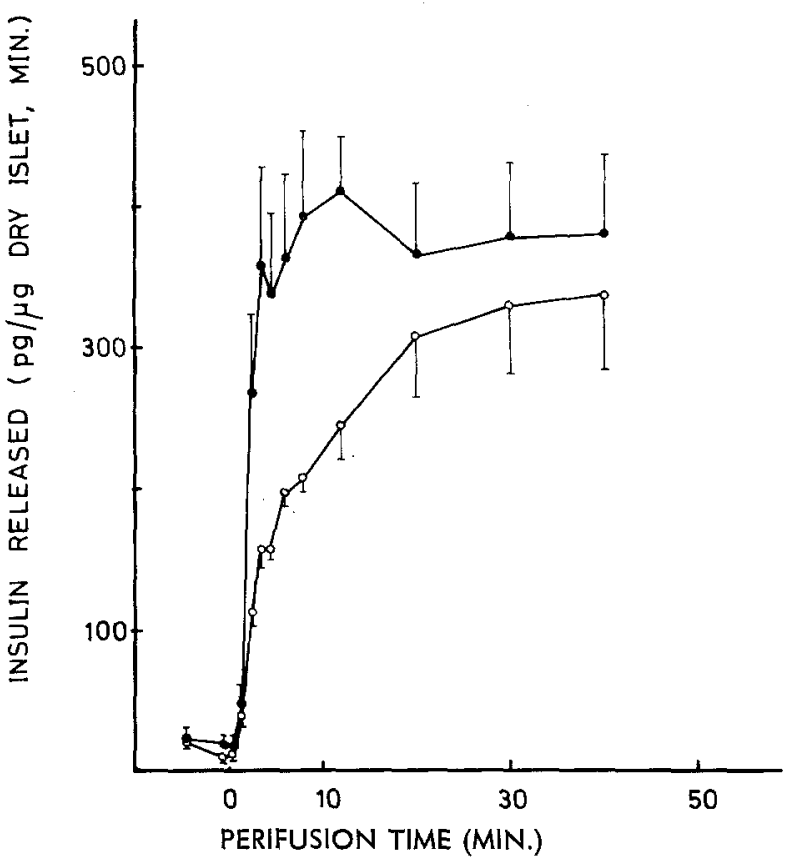

Fig. 5. Dynamics of glucose-induced insulin release in the presence of theophylline. Islets from fed (solid circles) and fasted (open circles) ob/ob-mice were perifused for $60 \mathrm{~min}$ with $\mathrm{KRB}$ buffer containing $5 \mathrm{mg} / \mathrm{ml}$ albumin, $3 \mathrm{mM}$ glucose and $5 \mathrm{mM}$ theophylline. At the end of this period two 1 min samples of effluent were taken for in. sulin assay. The medium was then changed to contain $17 \mathrm{mM}$ glucose. The moment of switching between medium reservoirs is denoted as zero time. Continuous sam. pling was then used over intervals of 1 or 2 min during the first $9 \mathrm{~min}$ and later over intervals of 6 or $10 \mathrm{~min}$. The average rate of insulin, release over each sampling period is given as mean values $\perp$ S.E.M. for 5 experiments

alterations of $\beta$-cell metabolism occur prior to the onset of glucose-stimulated insulin release. Both G6P and FDP rose significantly before there was any sign of stimulated secretion. This result is consistent with the demonstration of a prompt increase of reduced nicotinamide dinucleotides after exposing islets of $o b / o b$-mice to a sudden rise of the peri-insular glucose concentration $[25,26]$. Somewhat conflicting results have been presented by Matschinsky el al. [27], who reported that the islet concentration of G6P or 6-phosphogluconate did not rise until 5 min after the in vivo administration of glucose to rats. However, in those experiments the islet concentration of FDP and triose-P increased rapidly after the glucose load. It seems probable there- 
fore that variations in the extracellular glucose concentration induce very rapid changes of glucose meta $b$ olism in the $\beta$-cells of both rats and mice. The observation that at least in $o b / o b$-mice the rise of islet G6P is not only rapid but actually precedes the insulin secretory response is compatible with the hypothesis that glucose motabolism initiates insulin release [28, 29 ].

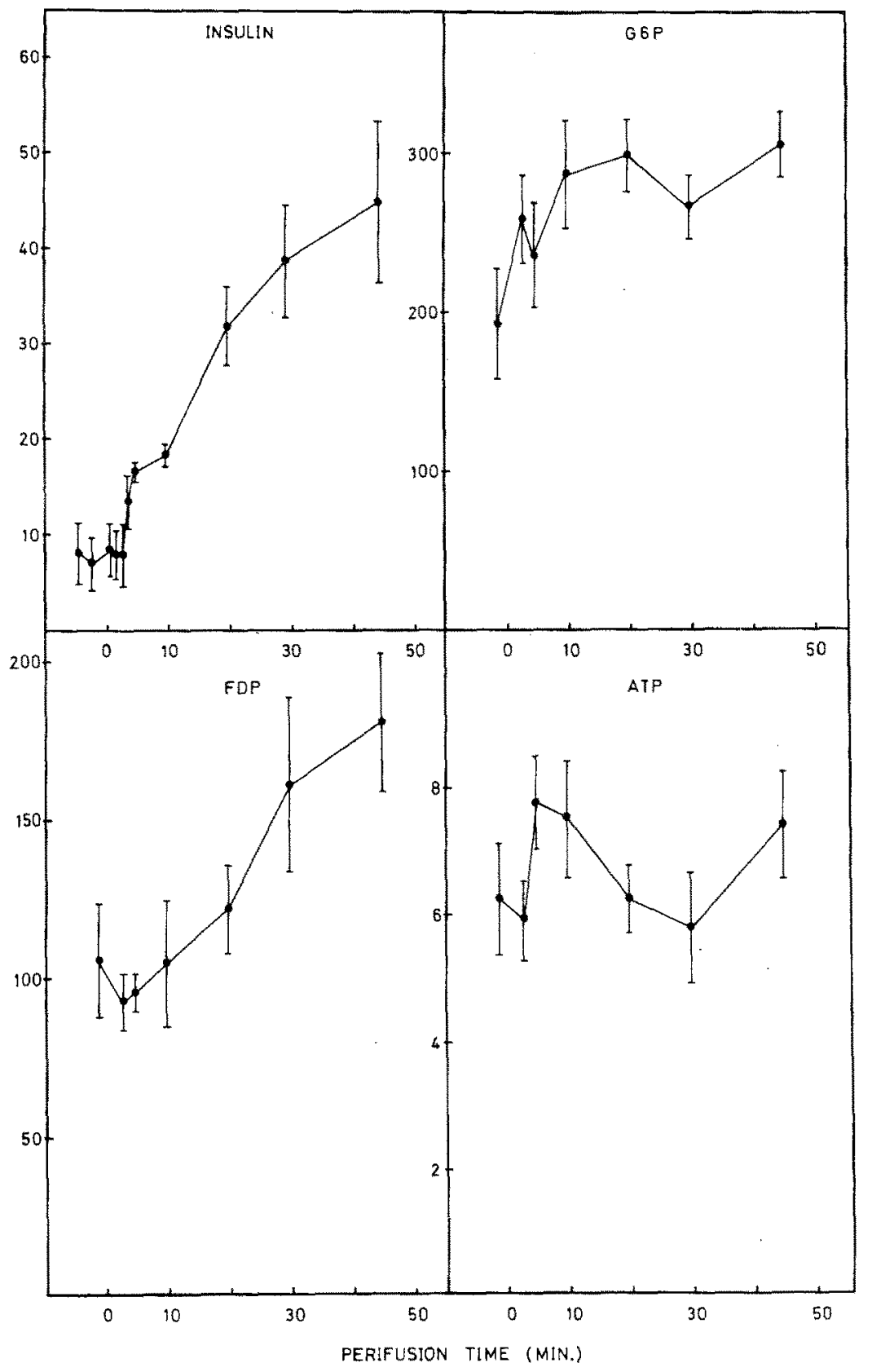

Fig. 6. Dynamies of insulin release and contents of G6P, FDP and ATP in response to glucose. Islets from fed ob/obmice perifused with KRB buffer. A 45-min period with $3 \mathrm{mM}$ glucose in the medium preceded the perifusion with $17 \mathrm{mM}$ glucose. $1 \mathrm{~min}$ samples of effluent were taken for insulin assay before and after the change between medium reservoirs at zero time. Insulin release is given as $p g / \mu g$ dry islet per min. Islet content of G6P or FDP is expressed as umoles/kg dry islet, and ATP as mmoles/kg dry islet. Mean values I S.E.M. for 6 experiments. Response of G6P and FDP levels to glucose was assessed by calculating the linear regression as a function of time. The regression coefficient for G6P is $1.89+0.73(p<0.05)$ and for FDP $1.98 \pm 0.26(p<0.001)$. Note that the use of a linear regres sion model in statistical testing does not imply that the substrate levels actually increased in a linear fashion. The increase of $\mathrm{G} 6 \mathrm{P}$ content during the first interval was $66.3 \pm 13.8 \mu$ moles $/ \mathrm{kg}$ dry islet $(p<0.005)$ calculated as in Fig. 2. Analysis of variance, using a two-way classification of the data, reveals a significant increase of the ATP content at 4, 10 and $45 \mathrm{~min}$ compared to the prestimulatory level (LSD $0.05=1.41 \mathrm{mmoles} / \mathrm{kg}$ dry islet) 
In animals as well as in man fasting makes the $\beta$-cells secrete less insulin than normal in response to glucose. Total blunting of the response was observed in mice deprived of food for 5 days [27]. In the present experiments the mice were fasted for only $17-18 \mathrm{~h}$, which reduced or abolished the primary response to glucose but left the late phase of secretion unaffected. Similar results were obtained by Malaisse et al. [30], who fasted rats for $24 \mathrm{~h}$; although the onset of insulin release was delayed, the late response appeared normal. However, several studies have revealed that even a prolonged fast does not prevent the serum insulin level from increasing quickly after a glucose load [31, 32]. One possible explanation for this apparent discrepancy between in vitro and in vivo experiments could be that in contradistinction to serum, the synthetic incubation

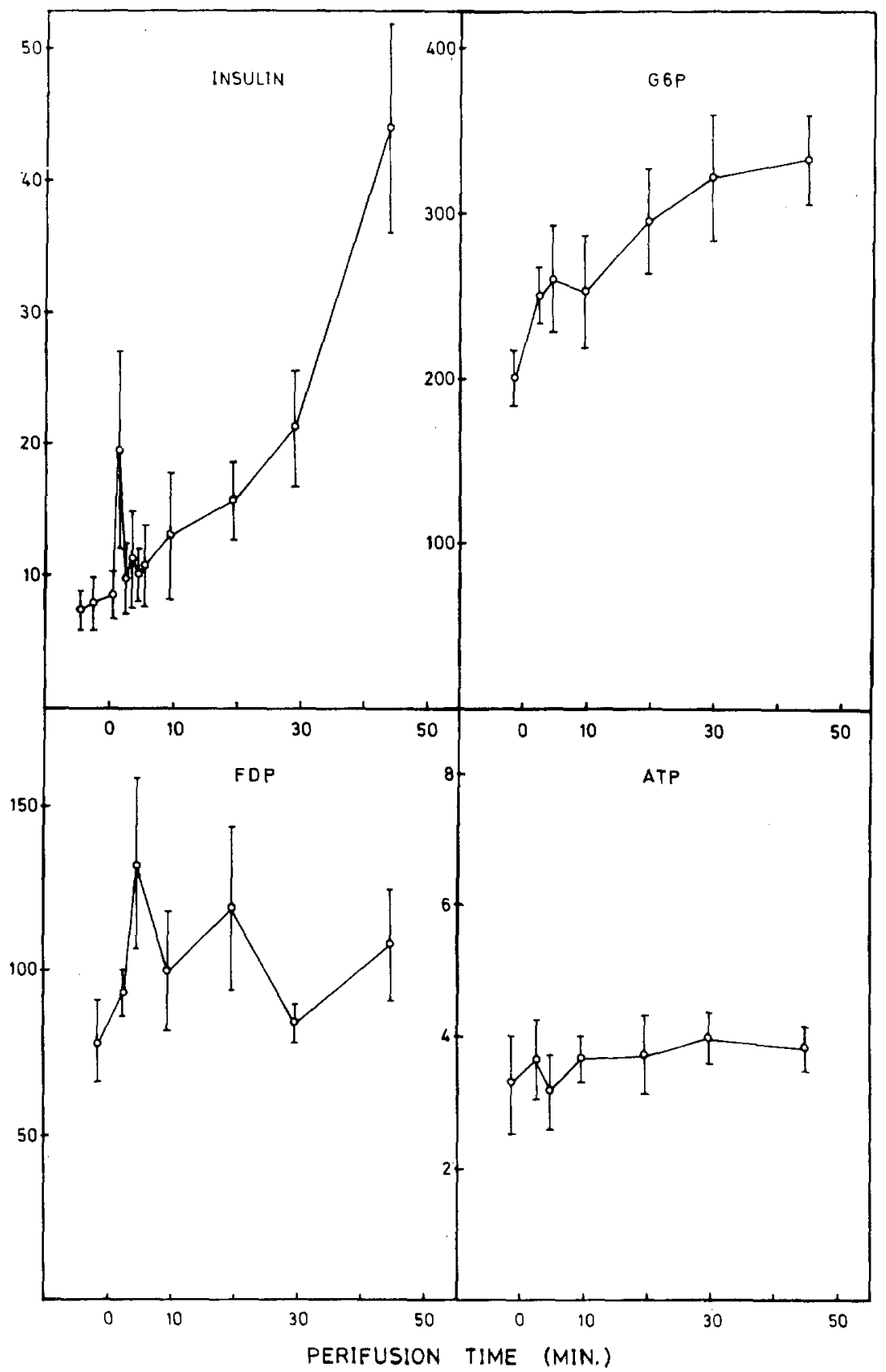

Fig. 7. Dynamics of insulin release and contents of G6P, FDP and ATP in response to glucose. Islets from fasted $o b / 0 b$-mice perifused with KRB buffer. The diagrams show the result of 6 experiments performed and presented as in Fig. 6 except that the donor animals were fasted for $18 \mathrm{~h}$. The regression coefficient for the G6P content as a function of time is $2.58 \pm 0.45(p<0.005)$. The difference in islet G6P content between 4 min and the prestimulatory level was $60.0 \pm 22.6 \mu$ moles $/ \mathrm{kg}$ dry islet $(p<0.05)$ calculated as in Fig. 2. 
media are poor in metabolic fuels. In early studies it was shown in witro that glutamate, pyruvate and fumarate enhance the glucose-stimulated insulin release [33]. It was therefore decided to compare the dynamics of insulin release in KRB buffer with those in a synthetic tissue culture medium (TCM 199). TCM 199 did not stimulate insulin release in itself but the responses to glucose were considerably greater than those observed in KRB buffer. The potentiating effect of TCM 199 was most propounced during the first $20 \mathrm{~min}$ of stimulation with glucose. However, the difference between islets from fed and fasted mice was essentially the same in TCM 199 as in KRB buffer.

Grey et al. [3] suggested that the inhibitory effect of fasting on glucose-induced insulin release might be due to a decline of glucose phosphorylating activity. This assumption appears to be supported by the data of Hedeskor [34], who studied the effects of fasting mice for $48 \mathrm{~h}$. When islets from the fasted animals were exposed to $16 \mathrm{mM}$ glucose for $30 \mathrm{~min}$, their content of G6P was markedly lower than the value recorded for islets of fed mice. On the other hand, Matschinsky et al. [27] observed no clear-cut effects of severe starvation on the islet content of G6P. These authors concluded that the drastic depression of the secretory response to glucose was not due to inhibition of glucose penetration, glucose phosphorylation or fructose-6-phosphate phosphorylation. It was found here that fasting for $18 \mathrm{~h}$ had no inhibitory effect on the glucose-jnduced increase of islet G6P, although the initial secretory response was suppressed. When KRB buffer was used as the basal perifusion medium, the content of ATP was lower in the islets from fasted mice than in those from fed mice. Only in the islets from fed mice did ATP and FDP increase in response to glucose stimulation. However, it is doubtful whether these metabolic effects are related to the delay of insulin secretion. The effect of fasting on insulin release was not eliminated by substituting TCM 199 for KRB buffer, although in TCM 199 the islet content of both FDP and ATP increased significantly in response to glucose.

A low secretory response to glucose has been observed not only after fasting but also in allegedly prediabetic humans [35] and in fetuses and newborns [36, $37]$. Interestingly, it has been reported that in all these conditions methylxanthines are able to relieve secretory inhibition [3, 38, 39]. This similarity suggests that fasting might be a convenient model for studying what is perhaps a basic defect in diabetes. In the present study theophylline did not eliminate the inhibition of glucose-stimulated insulin release induced by fasting. Although there was a marked potentiation of the glucose-induced response both in the islets of fed and fasted mice, theophylline made the effect of fasting appear even more striking. It seems therefore likely that theophylline potentiates glucose-stimulated insulin release by acting on some component of the secretory machinery which is distal to the one primarily affected by fasting.
Acknowtedgements. This work was supported by the Swedish Medical Research Council $(12 \mathrm{x}-562)$, the Medical Faculty of Umea and the Swedish Diabetes Association. The skilful technical assistance of Miss Sarah Andersson and Mrs Lilian Karlsson is also gratefully acknowledged.

\section{References}

1. Matschinsky, F.M., Ellerman, J.E.: Metabolism of gluease in the islets of Langerhans. J. biol. Chem. 243, $2730-2736(1908)$

2. Matschinsky, F.M., Landgraf, R., Ellerman, J, Kotler-Brajtburg, J.: Glucoreceptor mechanisms in islets of Langerhans. Diabetes 21 (suppl. 2), $555-569$ (1972)

3. Grey, N.J., Goldring, S., Kipnis, D.M.: The effect of fasting, diet, and actinomycin $\mathrm{D}$ on insulin secretion in the rat. J. clin. Invest. 49, 881-889, (1970)

4. Hellman, B.: Studies in obese-hyperglycemic mice. Ann. N.Y. Acad. Sci. 131, $541-558$ (1965)

5. Hellerström, C.: A method for the microdissection of intact pancreatic islets of mammals. Acta endocr. (Kbh.) 45, 122-132 (1964)

6. Umbreit, W.W., Burris, R.H., Stauffer, J.F. In: Manometric Techniques, p. 132. Minneapolis: Burgess Publishing Co. 1964

7. Salk, J., Youngner, J.S., Ward, E.: Method of preparing mixture 199. Amer. J. Hyg. 60, 225-230 (1954)

8. Idahl, L.-A.: A microperifusion device for panereatic islets allowing concomitant recordings of intermediate metabolites and insulin release. Anal. Biochern. 50, $386-398(1972)$

9. Lowry, O.H., Passonneau, J.V., Hasselberger, F.X., Schulz, D. W.: Effect of ischemia on known substrates and cofactors of the glycolytic pathway in brain. $J$. biol. Chem. 239, $18-30(\mathbf{1 9 6 4 )}$

10. Tdahl, L.-A., Hellman, B.: Microchemical assays of glucose and glucose 6 -phosphate in mammalian pancreatic $\beta$-cells. Acta endocr. (Kbh.) 59, 479-486 (1968)

11. Heding, L. G.: A simplified insulin radioimmunoassay method. In: Labelled Proteins in Tracer Studies, p. 345-351, Donato, L., Milhaud, G., Sirchis, J. (eds.). Brussels : Euratom 1966

12. Lowry, O.H., Passonneau, J.V., Schulz, D.W., Rock, M.K.: The measurement of pyridine nucleotides by enzymatic cycling. J, biol. Chem. 236, 2746-2755 (1961)

13. Matschinsky, F.M., Ellerman, J.E., Landgraf, R., Krzanowsli, J., Kotler-Brajtburg, J., Fertel, R.: Quantitative histochemistry of glucose metabolism in the islets of Langerhans. In: Recent Advances in Quantitative Histo- and Cytochemistry. Methods and Application, p. 143-182, Dubach, U.C., Schmidt, U. (eds.). Stuttgart: H. Huber Verlag, 1971

14. Matschinsky, F.M., Passonneau, J.V., Lowry, O.H.: Quantitative histochemical analysis of glycolytic intermediates and cofactors with an oil well method. $J$. Histochem. Cytochem. 16, 29-39 (1968)

15. Idahl, L,-A., Hurme, P., Wahlquist, $Y$., Hellman, B.: Pancreatic $\beta$-cell function and content of 6-phosphogluconate. Horm. Metab. Res. 3, 141-144 (1971)

16. Idahl, L.-A.: Glucose-6-phosphate content in mammalian pancreatic $\beta$-cells. Effects of various stimu. lators and inhibitors of insulin release. Hormones 2 , $371-377$ (1971)

17. Krzanowski, J.J., Fertel, R., Matschinsky, F.M.: Energy metabolism in pancreatic islets of rats. Diabetes $20,598-606(1971)$

18. Hellman, B., Sehlin, J., Täljedal, I.-B.: Evidence for mediated transport of glucose in mammalian pancre- 
atic $\beta$-cells. Biochim. biophys. Acta (Amst.) 241, $147-154(1971)$

19. Sehlin, J.: Effects of mannoheptulose on the dynamics of glucose oxidation in the pancreatic $\beta$-cells. FEBS Letters 30, 45-48 (1973)

20. Lernmark, A., Hellman, B.: The $\beta$-cell capacity for insulin secretion in microdissected pancreatic islets from obese-hyperglycemic mice. Life Sci. 8, 53-59 (1969)

21. Curry, D.L.: Is there a common beta cell insulin compartment stimulated by glucose and tolbutamide ? Amer. J. Physiol. 220, 319-323 (1971)

22. Gabbay, K.H., Tze, W.J.: Inhibition of glucoseinduced release of insulin by aldose reductase inhibitors. Proc. nat. Acad. Sci (Wash.) 69, 1435-1439 (1972)

23. Grodsky, G.M., Batts, A. A:, Bennett, L. L., Vcella, C., MoWilliams, N.B., Smith, D.F.: Effects of carbohydrates on secretion of insulin from isolated rat pancreas. Amer. J. Physiol. 205, $638-644$ (1963)

24. Landgraf, R., Kotler-Brajtburg, J., Maschinsky, F.M.: Kinetics of insulin release from the perfused rat pancreas caused by glucose, glucosamine, and galactose. Proc. nat. Acad. Sci. (Wash.) 68, 536-540 (1971)

25. Panten, U., Dal Ri, H., Poser, W., Hasselblatt, A.: Eine Methode der Gewebsumströmung für Fluorescenzmessungen. Pflügers Arch. ges. Physiol. 323, 86$90(1971)$

26. Panten, U., Kriegstein, E. v., Poser, W., Schönbrunn, J., Hasselblatt, A. : Effects of $\mathbf{I}$-leucine and a-ketoisocaproic acid upon insulin secretion and metabolism of isolated pancreatic islets. FEBS Letters 20, 225228 (1972)

27. Matschinsky, F.M., Ellerman, J.E., Krzanowski, J., Kotler-Brajtburg, J., Landgraf, R., Fertel, R.: The dual function of glucose in islets of Langerhans. $J$. biol. Chem. 246, 1007-1011 (1971)

28. Grodsky, G.M., Bennett, L.L., Smith, D.F., Schmid, F.G.: Effect of pulse administration of glucose or glucagon on insulin secretion in vitro. Metabolism 16, $222-233(1967)$

29. Ashcroft, S.J.H, Bassett, J.M., Randle, P.J.: Insulin secretion mechanisms and glucose metabolism in isolated islets. Diabetes 21, (suppl. 2), 538-545 (1972)

30. Malaisse, W.J., Malaisse-Lagae, F., Wright, P.H.: Effect of fasting upon insulin secretion in rat. Amer. J. Physiol. 213, 843-848 (1967)

31. Rasio, E.A., Soeldner, J.S., Cahill Jr., G.F.: Insulin and insulin-like activity in serum and extravascular fluid. Diabetologia 1, 125-127 (1965)

32. Cahill, G.F., Herrera, M. G., Morgan, A.P., Soeldner, J.S., Steinke, J., Levy, P.L., Reichard, Jr., G.A., Kipnis, D.M. : Hormone-fuel interrelationships during fasting. J. clin. Invest. 45, 1751-1769 (1966)

33. Coore, H.G., Randle, P.J.: Regulation of insulin secretion studied with pieces of rabbit pancreas incubated in vitro. Biochem. J. 93, 66-78 (1964)

34. Hedeskov, C.J.: Effect of fasting on insulin secretion and glucose metabolism in mouse islets. Diabetologia $8,363(1972)$

35. Cerasi, E., Luft, R.: Insulin response to glucose infusion in diabetic and non-diabetic monozygotic twin pairs. Genetic control of insulin response? Acta endocr. (Kbh.) 55, 330-345 (1967)

36. Burr, I.M., Kanazawa, Y., Marliss, E.B., Lambert, A.E.: Biphasic insulin release from perifused cultured fetal rat pancreas. Effects of glucose, pyruvate, and theophylline. Diabetes 20, 592-597 (1971)

37. Asplund, K.: Dynamics of insulin release from the foetal and neonatal rat pancreas. $J$, clin. Invest. in press

38. Cerasi, E., Luft, R.: The effect of an adenosine-3:, $5^{6}$ monophosphate diesterase inhibitior (Aminophylline) on the insulin response to glucose infusion in prediabetic and diabetic subjects. Horm. Metab. Res. 1, $162-168(1969)$

39. Heinze, E., Steinke, J.: Insulin secretion during development: Response of isolated pancreatic islets of fetal, newborn and adult rats to theophylline and arginine. Horm. Metab. Res, 4, 234-236 (1972)

Dr. L. $\AA$. Idahl

Department of Histology

University of Umeå

S-90187 Umeá 6

Sweden 